\title{
The Genetics of Autism Spectrum Disorder- A Review
}

\author{
GK KUNDU $^{\mathrm{a}}$, R ISLAM ${ }^{\mathrm{b}}$
}

\begin{abstract}
:
Autism spectrum disorder (ASD) is one of the most common neurodevelopmental disorders representing deficits in socialization, communication impairment, repetitive patterns of behaviors and/or restricted interest. The increasing prevalence of ASD worldwide is most likely due to increasing awareness, widening of the diagnostic concepts and availability of diagnostic framework. It is a genetically influenced disorders caused by factors including genetic, epigenetic factors that affect gene expression and activity and non-genetic factors like environmental exposures. It is widely thought to represent a disorder of connectivity, in which the environment interacts with the genome. It can occur as an association with genetic syndrome, can occur sporadically or may be familial.
\end{abstract}

\section{Introduction:}

Autism spectrum disorder (ASD) is a neurodevelopmental disorder characterized by qualitative impairment in social communication and interaction, repetitive behavior, and limited interest. It usually occur in early stage of child development (DSM-V). Autism was first outlined in 1943 by Leo Kanner, an Austrian-US-American Professor of Child Psychiatry. He described children with mental retardation and severe social isolation not explained by the developmental level of the children ${ }^{1}$. Kanner referred to Eugen Bleuler by naming the syndrome 'infantile autism' based on Bleulers schizophrenia criterion describing the loss of social interest in schizophrenia. At the same time, Professor Hans Asperger in Vienna, Austria, noticed similar patients with 'autistic psychopathy' and

a. Dr Gopen Kumar Kundu, Professor \& Chairman, Department. of Paediatric Neurology. Bangabandhu Sheikh Mujib Medical University. Dhaka.

b. Dr. Rumana Islam, MD- Phase- B (Resident), Paediatric Neurology \& Neurodevelopment, BSMMU, Dhaka

Address of Correspondence: Dr Gopen Kumar Kundu, Associate Professor \& Chairman, Department. of Paediatric Neurology. Bangabandhu Sheikh Mujib Medical University. Dhaka. Mobile : +8801718590768 Email: gopen.kundu@gmail.com Received: 17 Dec., 2020 Accepted: 06 April, 2021
Recognizing various phenotypic manifestations, it is understood that the underlying etiology of ASD is complex and genetic factors play an important role. The most significant advance in autism biology over the last decade has been in understanding the genetics of autism. The genetic diagnosis can benefit patients and the family by providing information, psychological support both immediate and long term and also can guide and help to prepare for the future. So, genetic diagnosis of ASD may offer opportunities for the identification of molecular targets for novel interventions, and provide new insight for families seeking genetic counseling.

(J Bangladesh Coll Phys Surg 2021; 39: 193-199) DOI: https://doi.org/10.3329/jbcps.v39i3.54166

normal intellectual abilities ${ }^{2}$. Hans Asperger noted that fathers of these children seemed aloof and socially isolated. Both, Kanner and Asperger, suspected a biological or even genetic origin of the disorder.

Based on the evidence reviewed, the median of prevalence estimates of autism spectrum disorders is $62 / 10,000$ worldwide $^{3}$. The prevalence of ASD ranged from $0.15-0.8 \%$ in Bangladesh and $3 \%$ In Dhaka ${ }^{4}$.Greater public awareness of autism has led to increased funding for autism research, yet the cause of ASD remains largely unknown because of the complex behavioral phenotypes and multigenic etiology of this disorder

Now It is believed that ASD is a result of complex geneenvironment interactions, with strong and clear genetic influences. Studies of twin pairs, high-risk infant siblings, families, and populations have estimated concordance rates and segregation of the disorder within families ${ }^{5}$. The concordance rate was reported as $60-70 \%$ in monozygous twins and as $5-30 \%$ in siblings ${ }^{5,6}$. A genetic basis for autism spectrum disorder (ASD) is now well established, and with the availability of highthroughput microarray and sequencing platforms, major advances have

been made in our understanding of genetic risk factors. A genetic basis for autism spectrum disorder (ASD) is 
now well established, and with the availability of highthroughput microarray and sequencing platforms, major advances have been made in the understanding of genetic risk factors. However, it is currently believed that over $50 \%$ of the risk of developing ASD is attributed to genetic variation ${ }^{7,8}$. Current evidence indicates that multiple genetic factors are the causative determinants of the majority of cases of autism ${ }^{9}$.

The objective of this paper is to review and to share the current knowledge regarding genetic variations in ASD, and its role in the identification of genetic biomarkers of ASD for diagnostic and therapeutic purposes.

\section{Genetic variants}

The genetic architecture of ASD is variable in different aspects, like- in frequency (common vs. rare variation), mode of inheritance (inherited vs. de novo variation), type of variation (single nucleotide, indel, or copy number variation) and mode of action (dominant, recessive, or additive $)^{7,8,10-12}$

Common variation means genetic variation from the reference genome, which is present in small number of population. Common variants with small effects are supposed to play a role in the development of complex traits in $\mathrm{ASD}^{13}$. Some study reported that the liability of ASD is mostly due to common variation in the genetic architecture, and that rare de novo mutations contribute to individual liability ( $49 \%$ of common inherited variants, $3 \%$ of de novo , $3 \%$ of rare inherited variants, and $41 \%$ of unaccounted) ${ }^{12}$ to develop ASD.Confirmation of the most specific, consistently replicated, and highly effective common variants may also involve in the pathogenesis of ASD. These genes are generally responsible for the development of the brain \& its structure, and the synthesis of neurotransmitters and neuromodulators. The genes responsible for autism have been classified into two groups, "syndromic autism-related genes" (that lead to symptoms related to autism such as fragile X syndrome, Rett syndrome) and "nonsyndromic autism-related genes" (frequently being autism susceptible genes). The genomes of people differ from each other in genetic variants called single nucleotide polymorphisms (SNPs). Despite that most of these variants are common and occur at least in 1\% of the population, some of these SNPs may increase the risk of developing complex, polygenic diseases ${ }^{40}$. Several large-scale sequencing, including those that examine the entire coding region of the genome (whole exome sequencing) and the entire genome (whole genome sequencing) are now being performed.

\section{Monogenic syndromes associated with ASD}

Approximately $5-10 \%$ of ASD patients have cooccurring monogenic syndromes or disorders. The most common ASD-related syndrome is fragile X syndrome (FXS) diagnosed in about $1.5-3 \%$ of individuals with ASD. FXS is caused by mutations in the FMR1 gene that regulates about 6000 mRNAs in the brain and plays an essential role in synaptic plasticity ${ }^{14}$. Another frequent $\mathrm{ASD}$-related syndrome is tuberous sclerosis complex (TSC) which occurs in about $1 \%$ of patients diagnosed with ASD. Two causative genes, TSC1 and TSC2, are inhibitors in the mammalian target of the rapamycin signaling pathway (mTOR) that is involved in the local translation in the central nervous system. Mutations in the MECP2 gene are responsible for Rett syndrome that is found in an additional $1 \%$ of female ASD patients. The MeCP2 protein (methyl CpG-binding protein 2) is a transcription factor that regulates the expression of many genes in neurons ${ }^{15}$.

Moreover, mutations in the PTEN gene that indirectly suppress the mTOR pathway are responsible for spectrum phenotypes including ASD with macrocephaly ${ }^{16}$. Other examples of single-gene syndromes associated with ASD include neurofibromatosis type 1 (NF1 gene), Duchenne muscular dystrophy (DMD gene), and Timothy syndrome (CACNA1C gene). ASD can also occur in some metabolic diseases such as phenylketonuria (PAH gene) and Smith-Lemli-Opitz syndrome (DHCR7 gene $)^{18}$. Several studies have proposed that another group of ASD related to monogenic disorders is caused by mutations in the mitochondrial DNA (mtDNA) and impairment of mitochondrial energy metabolism ${ }^{18,19}$.

\section{Chromosomal abnormalities}

Cytogenetic assays have long been used to uncover chromosomal defects in patients with autism, and a number of cytogenetic abnormalities have been described till date. Less than $10 \%$ of cases of autism are associated with chromosomal abnormalities ${ }^{15}$. Using various stains, the chromosomes of patients with autism are analyzed for visible breakpoints, translocations, duplications, and deletions. These regions are then 
scrutinized for the presence of genes that potentially are involved in the pathogenesis of ASD.

Classical karyotyping techniques can reveal chromosomal aberrations in approximately $2-5 \%$ of ASD individuals ${ }^{15-20}$. Most of structural aberrations are rare and their causal role in ASD is not clear, but few of them are recurrent ${ }^{21}$. The most frequent chromosomal abnormality detected in $1-3 \%$ children with ASD is maternally derived 15q11q13 duplication, with variable size $^{22}$.Many genes in this chromosomal region have essential functions in the brain, such as GABRA5 and GABRB3 (GABA receptors), UBE3A and HERC2 (components of the proteasome complex) and SNRPN (ribonucleoprotein peptide N) as well as CYFIP1 (the FMRP interacting protein) ${ }^{23-26}$. Other chromosomal abnormalities identified in ASD patients include aneuploidies: 21 (Down syndrome), X (Turner syndrome, Klinefelter syndrome, XXX syndrome), and Y (XYY syndrome $)^{20}$.

With the availability of microarray offering higher resolution genome scanning, duplication or deletion of segments of the genome have been described among individuals with ASD. It can detect chromosomal micro deletions and micro duplications that are difficult to identify by karyotyping. Research studies have shown that clinically relevant CNVs (copy number variants) in $7-14 \%$ of patients with idiopathic $\mathrm{ASD}^{10,27,28}$. Rare de novo $\mathrm{CNV}$ s are identified more frequent in individuals with sporadic ASD than in autistic cases with affected sibling ${ }^{29}$. Similar results were obtained in further studies that identified de novo CNVs in $5.8-8.4 \%$ of sporadic $\mathrm{ASD}^{30-32}$. The most common recurrent ASD associated $\mathrm{CNVs}$ are the approximately $600 \mathrm{~kb}$ micro deletions and micro duplications at the $16 \mathrm{p} 11.2$ region that are identified in about $1 \%$ of ASD individuals ${ }^{33-34}$. Another recurrent CNVs detected in ASD cases include 1q21.1, $15 \mathrm{q} 13.3,17 \mathrm{p} 11.2,22 \mathrm{q} 11.2,16 \mathrm{p} 13.1$ and micro duplication of $7 \mathrm{q} 11.23^{30,35}$. Furthermore, microarray analysis revealed several non-recurrent micro deletion including regions of 2p16.3, 7q22q31, 22q13.3, and Xp22 ${ }^{30,36,37}$.

Some ASD-associated CNVs are inherited from an unaffected parent or are found in control populations which prove different penetrance of these CNVs. Moreover, the same CNVs are detected both in ASD cases and in patients with other neurocognitive disorders including mental retardation/DD, epilepsy, schizophrenia, bipolar disorder, and ADHD that suggest that the final phenotype depend on the occurrence of additional rare genetic (or non-genetic) factors ${ }^{38}$.

\section{Synaptic genes}

Many synaptic protein genes are associated with the pathogenesis of ASDs. A common breakdown found at the level of synapse formation and stabilization, as well as of the ability of synapses to be modified by experience through plasticity mechanisms. Synapse dysfunctions are also found correlated with ASD and other neuropsychiatric disorders with unknown etiology, such as schizophrenia and intellectual disabilities ${ }^{39}$ as well as epilepsy ${ }^{40}$.

Based on different studies regarding ASD, the most consistently reported genetic abnormalities are mutations in synaptic genes, including neuroligins (NLGN ), SH3 and multiple ankyrin repeat domains (SHANK), neurexin (NRXN) families, and contactin associated protein-like2 (CNTNAP2 $)^{41}$.

Neuroligins are cell-adhesion molecules involved in formation and remodeling of central nervous system synapses, found on different loci of X-chromosome. A group in France has identified mutations of the neuroliginsNLGN3 (at Xq13) and NLGN4(at Xp22.3) in a study with 158 multiplex ASD families ${ }^{42}$.Neuroligin aggregation is synaptogenic, but exhibits specificity: NLGN1, NLGN3 and NLGN4 link to glutamatergic postsynaptic proteins, but NLGN2 associated with both glutamatergic and GABAergic postsynaptic proteins ${ }^{43}$.

Other genes associated with ASD is the SHANK genes (SHANK1, SHANK2 and SHANK3), encoding synaptic proteins that may function as molecular scaffolds in the postsynaptic density of excitatory synapses ${ }^{41}$.SHANK3 is the most widely studied $\&$ rare de novo mutations located in chromosome 22q13.3, identified in probands and families with ASD in many studies $^{44}$. The inheritance pattern of SHANK 3 mutations is variable; transmission from healthy parents and existence in unaffected siblings were reported ${ }^{44,45,46}$.

Other important synaptic genes are NRXN1, NRXN2 and NRXN3, encoding neurexin. This trans-synaptic complex is necessary for efficient neurotransmission, and they are involved in the formation of synaptic contacts by interaction withneurologin ${ }^{47}$.In Large cohort studies a higher rate of deletions in the NRXN1 
region found, located in the probands of chromosome 2 p16.3 associated with ASD, compared to healthy controls, also an overrepresentation of small-sized inverted repeats found ${ }^{48}$.

Several family-based association studies identified a common variant (rs7794745) that was associated with increased risk of autism, and an amino acid substitution in the CNTNAP2 protein in children with autism also found ${ }^{49,50}$. But in a large-sized GWAS study failed to demonstrate a significant association of the findings found in the previous studies, and no associations between rare heterogeneous mutations of CNTNAP2 and ASD were observed ${ }^{51,52}$. Though CNTNAP2 is still regarded as one of the important causative genes of ASD that warrants further studies ${ }^{53}$.

These findings indicate that, the possibility of ASD might be caused by abnormalities in synaptic plasticity, as the proteins described play essential roles in synaptic development and modification. Despite of low frequency of de novo mutations, inconsistencies in genetic analysis results, and phenotypic heterogeneity, synapse-related genes are crucial candidates of ASD, and provide baseline evidence for further studies.

Neurotransmitter Systems in Autism Spectrum Disorder

Neurotransmitters connect neurons with each other; also have key roles in normal development of brain, memory and behavior regulation. Neurotransmitter system dysfunction may be a cause of Autism Spectrum Disorder (ASD), by affecting neuronal cell migration, differentiation and synaptogenesis and eventually developmental processes of the brain ${ }^{54}$.Most common neurotransmitter associated with the pathogenesis of ASD are, GABAergic, glutamatergic and serotonergic systems $^{55}$.

Neurochemical abnormality thought to be associated with pathophysiology of ASD is the reduction in the expression of GAD65 and GAD67, that are required for the conversion of glutamate to GABA, which cause suppression of GABAergic inhibition ${ }^{56}$ and also detection of low platelet GABA levels in children with $\mathrm{ASD}^{57}$.

Two opposite hypotheses regarding the role of glutamatergic system have been proposed ${ }^{58}$. So, there is a doubt, whether the ASD individuals hyper or hypoglutamatergic. New researches has focused more in hyper-glutamatergic state ${ }^{54}$.
Like glutamate hypothesis there is also doubt about serotonin neurotransmitter systems. Two main findings of serotonin hypothesis in patients with ASD are increased or decreased brain serotonin levels ${ }^{59}$. The serotonin transporter gene $(5-H T T)$ has been examined in several .

Relationship of dopamine and norepinephrine with ASD was gathered from different studies \& decrease in DBH (Dopamine B Hydroxylase)activity found, which relates to chromosome 9q34, and increased serum norepinephrine levels in children with autism and in their parents also found ${ }^{60}$.

Chemical and histochemical studies in the brains of patients with ASD has shown loss of nicotinic receptors, basal forebrain cholinergic neurons also found abnormally large and surplus ${ }^{54}$.Decreased number of the neuronal - 4 nicotinic acetylcholinereceptor subunits, linked to chromosome 20q13.2- q13.3 in postmortem parietal neocortex and cerebellum of individuals with autism compared to normal control subjects and individuals with mental retardation without autism $^{61}$.

Oxytocin (OT) is also relevant to the impaired sociability of autism. Two genome-wide screens have found linkage in autism to the chromosome 3p25-p26 locus containing the OT receptor gene ${ }^{62}$.

\section{Conclusion:}

Autism is the fastest growing neuro-developmental disorder. Genetics has been found to play an extensive role in autism. The genetics underlying autism are incredibly complex. Although various genes and proteins have been associated with the development of autism, very little is known about their specific role in dysfunction of the brain leading to autism. Ongoing research beyond genes is being carried out to find other factors such as environment or gene-environment interactions that can contribute in the development of autism as the disorder shows a high phenotypic variability and additional genetic heterogeneity.

\section{References:}

1. Kanner L. Autistic disturbances of affective contact. Nervous child. 1943;2(3):217-50.

2. Asperger H. Die "AutistischenPsychopathen". imKindesalter, Archives fur Psychiatrie und Nervenkrankheitem 117, 67-136. Translated in U. Frith. 
Autism and Asperger's syndrome. 1944:39-92.https:// doi.org/10.1007/BF01837709

3. Elsabbagh M, Divan G, Koh YJ, Kim YS, Kauchali S, Marcín $\mathrm{C}$, et al. Global prevalence of autism and other pervasive developmental disorders. Autism research. 2012;5(3):16079.https://doi.org/10.1002/aur.239, PMid:22495912 PMCid:PMC3763210

4. Hossain MD, Ahmed HU, Uddin MJ, Chowdhury WA, Iqbal MS, Kabir RI, et al. Autism Spectrum disorders (ASD) in South Asia: a systematic review. BMC psychiatry. 2017;17(1):1-7.https://doi.org/10.1186/s12888-0171440-x,PMid:28826398 PMCid:PMC5563911

5. Bailey A, Le Couteur A, Gottesman I, Bolton P, Simonoff E, Yuzda E, et al. Autism as a strongly genetic disorder: evidence from a British twin study. Psychological medicine. $1995 ; 25$ (1):63-77.https://doi.org/10.1017/ S0033291700028099,PMid:7792363

6. Ozonoff S, Young GS, Carter A, Messinger D, Yirmiya N, Zwaigenbaum L, et al. Recurrence risk for autism spectrum disorders: a Baby Siblings Research Consortium study. Pediatrics. 2011;128(3):e488-e95,https://doi.org/10.1542/ peds.2010-2825,PMid:21844053 PMCid:PMC3164092

7. De Rubeis S, Buxbaum JD. Genetics and genomics of autism spectrum disorder: embracing complexity. Human molecular genetics. 2015;24(R1):R24-R31.https://doi.org/10.1093/ hmg/ddv273PMid:26188008 PMCid:PMC4675826

8. Hallmayer J, Cleveland S, Torres A, Phillips J, Cohen B, Torigoe $\mathrm{T}$, et al. Genetic heritability and shared environmental factors among twin pairs with autism. Archives of general psychiatry. 2011;68(11):1095102.https://doi.org/10.1001/archgenpsychiatry. 2011.76,PMid:21727249 PMCid: PMC4440679

9. Rutter M, Bailey A, Bolton P, Le Couteur A. Autism and known medical conditions: myth and substance. Journal of Child Psychology and Psychiatry. 1994;35(2):311-22. https://doi.org/10.1111/j.1469-7610.1994.tb01164.x, PMid:8188801

10. Geschwind DH, State MW. Gene hunting in autism spectrum disorder: on the path to precision medicine. The Lancet Neurology. 2015;14(11):1109-20.https://doi.org/10.1016/ S1474-4422(15)00044-7

11. Voineagu I, Yoo HJ. Current progress and challenges in the search for autism biomarkers. Disease markers. 2013; 35(1):55-65.https://doi.org/10.1155/2013/476276,PMid: 24167349 PMCid:PMC3774962

12. Gaugler T, Klei L, Sanders SJ, Bodea CA, Goldberg AP, Lee $\mathrm{AB}$, et al. Most genetic risk for autism resides with common variation. Nature genetics. 2014;46(8):881.https://doi.org/ 10.1038/ng.3039.PMid:25038753 ,PMCid:PMC4137411

13. Klei L, Sanders SJ, Murtha MT, Hus V, Lowe JK, Willsey AJ, et al. Common genetic variants, acting additively, are a major source of risk for autism. Molecular autism. 2012;3(1):9.https://doi.org/10.1186/2040-2392-3-9.PMid: 23067556, PMCid:PMC3579743

14. Ascano M, Mukherjee N, Bandaru P, Miller JB, Nusbaum JD, Corcoran DL, et al. FMRP targets distinct mRNA sequence elements to regulate protein expression. Nature. 2012;492(7429):382.https://doi.org/10.1038/nature 11737.PMid:23235829, PMCid:PMC3528815

15. Liu X, Takumi T. Genomic and genetic aspects of autism spectrum disorder. Biochemical and Biophysical Research Communications. 2014;452(2):244-53. https://doi.org/ 10.1016/j.bbrc.2014.08.108

16. Herman GE, Butter E, Enrile B, Pastore M, Prior TW, Sommer A. Increasing knowledge of PTEN germline mutations: Two additional patients with autism and macrocephaly. American journal of medical genetics Part A. 2007;143(6):589-93. https://doi.org/10.1002/ajmg.a. 31619.PMid: 17286265

17. Caglayan AO. Genetic causes of syndromic and non syndromic autism. Developmental Medicine \& Child Neurology. 2010;52(2):130-8.https://doi.org/10.1111/ j.1469-8749.2009.03523.xPMid:20059518

18. Wang Y, Picard M, Gu Z. Genetic evidence for elevated pathogenicity of mitochondrial DNA heteroplasmy in autism spectrum disorder. PLoS genetics. 2016;12(10): e $1006391 . h t t p s: / / d o i . o r g / 10.1371 /$ journal.pgen. 1006391.PMid:27792786, PMCid:PMC5085253

19. Valiente-Pallejà A, Torrell H, Muntané G, Cortés MJ, Martínez-Leal R, Abasolo N, et al. Genetic and clinical evidence of mitochondrial dysfunction in autism spectrum disorder and intellectual disability. Human molecular genetics. 2018;27(5):891-900.https://doi.org/10.1093/ hmg/ddy009,PMid:29340697

20. Devlin B, Scherer SW. Genetic architecture in autism spectrum disorder. Current opinion in genetics \& development. 2012;22(3):229-37.https://doi.org/10.1016/ j.gde.2012.03.002PMid:22463983

21. Castermans D, Wilquet V, Steyaert J, van de Ven W, Fryns J-P, Devriendt K. Chromosomal anomalies in individuals with autism: a strategy towards the identification of genes involved in autism. Autism. 2004;8(2):141-61.https:// doi.org/10.1177/1362361304042719.PMid:15165431

22. Hogart A, Wu D, LaSalle JM, Schanen NC. The comorbidity of autism with the genomic disorders of chromosome 15q11. 2-q13. Neurobiology of disease. 2010;38(2):181-91.https:/ /doi.org/10.1016/j.nbd.2008.08.011.PMid:18840528, PMCid:PMC2884398

23. Kwasnicka-Crawford DA, Roberts W, Scherer SW. Characterization of an autism-associated segmental maternal heterodisomy of the chromosome 15q11-13 region. Journal of autism and developmental disorders. 2007;37(4):694-702. https://doi.org/10.1007/s10803-0060225-8PMid: 17006779 
24. Nishimura Y, Martin CL, Vazquez-Lopez A, Spence SJ, Alvarez-Retuerto AI, Sigman M, et al. Genome-wide expression profiling of lymphoblastoid cell lines distinguishes different forms of autism and reveals shared pathways. Human molecular genetics. 2007;16(14):168298.https://doi.org/10.1093/hmg/ddm116.PMid:17519220

25. Bucan M, Abrahams BS, Wang K, Glessner JT, Herman EI, Sonnenblick LI, et al. Genome-wide analyses of exonic copy number variants in a family-based study point to novel autism susceptibility genes. PLoS genetics. 2009; 5(6),https://doi.org/10.1371/journal.pgen. 1000536 PMid: 19557195 PMCid:PMC2695001

26. Puffenberger EG, Jinks RN, Wang H, Xin B, Fiorentini C, Sherman EA, et al. A homozygous missense mutation in HERC2 associated with global developmental delay and autism spectrum disorder. Human mutation. 2012; 33(12):1639-46.https://doi.org/10.1002/humu.22237 PMid:23065719

27. Rosenfeld JA, Ballif BC, Torchia BS, Sahoo T, Ravnan JB, Schultz R, et al. Copy number variations associated with autism spectrum disorders contribute to a spectrum of neurodevelopmental disorders. Genetics in Medicine. 2010; 12(11):694.https://doi.org/10.1097/GIM.0b013e3181 f0c5f3.PMid:20808228

28. Roberts JL, Hovanes K, Dasouki M, Manzardo AM, Butler MG. Chromosomal microarray analysis of consecutive individuals with autism spectrum disorders or learning disability presenting for genetic services. Gene. 2014;535(1):70-8.https://doi.org/10.1016/j.gene.2013. 10.020PMid:24188901 PMCid:PMC4423794

29. Sebat J, Lakshmi B, Malhotra D, Troge J, Lese-Martin C, Walsh T, et al. Strong association of de novo copy number mutations with autism. Science. 2007;316(5823):445-9. https://doi.org/10.1126/science.1138659, PMid:17363630 PMCid:PMC2993504

30. Marshall CR, Noor A, Vincent JB, Lionel AC, Feuk L, Skaug J, et al. Structural variation of chromosomes in autism spectrum disorder. The American Journal of Human Genetics. 2008;82(2):477-88.https://doi.org/10.1016/j. ajhg.2007.12.009.PMid:18252227, PMCid:PMC2426913

31. Levy D, Ronemus M, Yamrom B, Lee Y-h, Leotta A, Kendall $\mathrm{J}$, et al. Rare de novo and transmitted copy-number variation in autistic spectrum disorders. Neuron. 2011;70(5):88697.https://doi.org/10.1016/j.neuron.2011.05.015. PMid: 21658582

32. Sanders SJ, Ercan-Sencicek AG, Hus V, Luo R, Murtha MT, Moreno-De-Luca D, et al. Multiple recurrent de novo CNVs, including duplications of the 7q11. 23 Williams syndrome region, are strongly associated with autism. Neuron. 2011;70(5):863-85.https://doi.org/10.1016/j.neuron. 2011.05.002.PMid:21658581, PMCid:PMC3939065

33. Weiss LA, Shen Y, Korn JM, Arking DE, Miller DT, Fossdal $\mathrm{R}$, et al. Association between microdeletion and microduplication at 16p11. 2 and autism. New England Journal of Medicine. 2008;358(7):667-75.https://doi.org/ 10.1056/NEJMoa075974.PMid:18184952

34. Fernandez BA, Roberts W, Chung B, Weksberg R, Meyn S, Szatmari $\mathrm{P}$, et al. Phenotypic spectrum associated with de novo and inherited deletions and duplications at 16p11. 2 in individuals ascertained for diagnosis of autism spectrum disorder. Journal of medical genetics. 2010;47(3):195-203. https://doi.org/10.1136/jmg.2009.069369.PMid:19755429

35. Tropeano M, Ahn JW, Dobson RJ, Breen G, Rucker J, Dixit A, et al. Male-biased autosomal effect of 16p13.11 copy number variation in neurodevelopmental disorders. PloS one. 2013;8(4):e61365.https://doi.org/10.1371/journal. pone.0061365.PMid:23637818 PMCid:PMC3630198

36. Prasad A, Merico D, Thiruvahindrapuram B, Wei J, Lionel $\mathrm{AC}$, Sato D, et al. A discovery resource of rare copy number variations in individuals with autism spectrum disorder. G3: Genes, Genomes, Genetics. 2012;2(12):1665-85.https:// doi.org/10.1534/g3.112.004689.PMid:23275889 PMCid: PMC3516488

37. Béna F, Bruno DL, Eriksson M, van Ravenswaaij Arts C, Stark Z, Dijkhuizen T, et al. Molecular and clinical characterization of 25 individuals with exonic deletions of NRXN1 and comprehensive review of the literature. American Journal of Medical Genetics Part B: Neuropsychiatric Genetics. 2013;162(4):388-403.https:// doi.org/10.1002/ajmg.b.32148.PMid:23533028

38. Girirajan S, Eichler EE. Phenotypic variability and genetic susceptibility to genomic disorders. Human molecular genetics. 2010;19(R2):R176-R87.,https://doi.org/10.1093/ hmg/ddq366PMid:20807775 PMCid:PMC2953748

39. Ripke S, Sanders AR, Kendler KS, Levinson DF, Sklar P, Holmans PA, et al. Genome-wide association study identifies five new schizophrenia loci. Nature genetics. 2011; 43(10):969.https://doi.org/10.1038/ng.940.PMid: 21926974,PMCid:PMC3303194

40. Giovedí S, Corradi A, Fassio A, Benfenati F. Involvement of synaptic genes in the pathogenesis of autism spectrum disorders: the case of synapsins. Frontiers in pediatrics. 2014;2:94.https://doi.org/10.3389/fped.2014.00094. PMid:25237665,PMCid:PMC4154395

41. Yoo H. Genetics of autism spectrum disorder: current status and possible clinical applications. Experimental neurobiology. 2015;24(4):257-72.,https://doi.org/10.5607/ en.2015.24.4.257PMid:26713075 PMCid:PMC4688327

42. Jamain S, Quach H, Betancur C, Råstam M, Colineaux C, Gillberg IC, et al. Mutations of the X-linked genes encoding neuroligins NLGN3 and NLGN4 are associated with autism. Nature genetics. 2003;34(1):27.https://doi.org/10.1038/ ng1136.PMid:12669065, PMCid:PMC1925054

43. Graf ER, Zhang X, Jin S-X, Linhoff MW, Craig AM. Neurexins induce differentiation of GABA and glutamate postsynaptic specializations via neuroligins. Cell. 
2004;119(7):1013-26.https://doi.org/10.1016/j.cell.2004. 11.035.PMid:15620359, PMCid:PMC2826211

44. Durand CM, Betancur C, Boeckers TM, Bockmann J, Chaste $\mathrm{P}$, Fauchereau F, et al. Mutations in the gene encoding the synaptic scaffolding protein SHANK3 are associated with autism spectrum disorders. Nature genetics. 2007; 39(1): 25.https://doi.org/10.1038/ng1933.PMid: 17173049, PMCid:PMC2082049

45. Moessner R, Marshall CR, Sutcliffe JS, Skaug J, Pinto D, Vincent $\mathrm{J}$, et al. Contribution of SHANK3 mutations to autism spectrum disorder. The American Journal of Human Genetics. 2007;81(6):1289-97.https://doi.org/10.1086/ 522590. PMid:17999366, PMCid:PMC2276348

46. Durand CM, Perroy J, Loll F, Perrais D, Fagni L, Bourgeron $\mathrm{T}$, et al. SHANK3 mutations identified in autism lead to modification of dendritic spine morphology via an actindependent mechanism. Molecular psychiatry. 2012;17(1): 71.,https://doi.org/10.1038/mp.2011.57PMid:21606927 PMCid:PMC3252613

47. Reissner C, Klose M, Fairless R, Missler M. Mutational analysis of the neurexin/neuroligin complex reveals essential and regulatory components. Proceedings of the National Academy of Sciences. 2008;105(39):15124-9., https://doi.org/10.1073/pnas.0801639105P Mid: 18812509, PMCid:PMC2551626

48. Chen X, Shen Y, Zhang F, Chiang C, Pillalamarri V, Blumenthal I, et al. Molecular analysis of a deletion hotspot in the NRXN1 region reveals the involvement of short inverted repeats in deletion CNVs. The American Journal of Human Genetics. 2013;92(3):375-86.https://doi.org/ 10.1016/j.ajhg.2013.02.006.PMid:23472757, PMCid: PMC3591860

49. Alarcón M, Abrahams BS, Stone JL, Duvall JA, Perederiy JV, Bomar JM, et al. Linkage, association, and geneexpression analyses identify CNTNAP2 as an autismsusceptibility gene. The American Journal of Human Genetics. 2008;82(1):150-9.https://doi.org/10.1016/j.ajhg. 2007.09.005.PMid:18179893, PMCid:PMC2253955

50. Arking DE, Cutler DJ, Brune CW, Teslovich TM, West K, Ikeda $\mathrm{M}$, et al. A common genetic variant in the neurexin superfamily member CNTNAP2 increases familial risk of autism. The American Journal of Human Genetics. 2008; 82(1):160-4.https://doi.org/10.1016/j.ajhg.2007. 09.015.PMid:18179894, PMCid:PMC2253968

51. Ma D, Salyakina D, Jaworski JM, Konidari I, Whitehead $\mathrm{PL}$, Andersen AN, et al. A genome wide association study of autism reveals a common novel risk locus at 5 p14. 1 . Annals of human genetics. 2009;73(3):263-73.,https:// doi.org/10.1111/j.1469-1809.2009.00523.x PMid:19456320 PMCid:PMC2918410

52. Murdoch JD, Gupta AR, Sanders SJ, Walker MF, Keaney J, Fernandez TV, et al. No evidence for association of autism with rare heterozygous point mutations in contactinassociated protein-like 2 (CNTNAP2), or in other contactin-associated proteins or contactins. PLoS genetics. 2015;11(1):e1004852.https://doi.org/10.1371/journal. pgen.1004852,PMid:25621974 ,PMCid: PMC4306541

53. Chiocchetti A, Kopp M, Waltes R, Haslinger D, Duketis E, Jarczok T, et al. Variants of the CNTNAP2 52 promoter as risk factors for autism spectrum disorders: a genetic and functional approach. Molecular psychiatry. 2015;20(7):839. https://doi.org/10.1038/mp.2014.103PMid:25224256

54. Cetin FH, Tunca H, Guney E, Iseri E. Neurotransmitter systems in autism spectrum disorder. Autism Spectrum Disorder-Recent Advances. 2015.https://doi.org/10.5772/ 59122

55. Trottier G, Srivastava L, Walker C-D. Etiology of infantile autism: a review of recent advances in genetic and neurobiological research. Journal of Psychiatry and Neuroscience. 1999;24(2):103.

56. Hussman JP. Suppressed GABAergic inhibition as a common factor in suspected etiologies of autism. J Autism DevDisord. 2001;31(2):247-8.https://doi.org/10.1023/A:10107156 19091PMid: 11450824

57. Rolf L, Haarmann F, Grotemeyer KH, Kehrer H. Serotonin and amino acid content in platelets of autistic children. ActaPsychiatricaScandinavica. 1993;87(5):312-6.https:// doi.org/10.1111/j.1600-0447.1993.tb03378. x.PMid:851717058. Rojas DC. The role of glutamate and its receptors in autism and the use of glutamate receptor antagonists in treatment. Journal of neural transmission. 2014;121(8):891-905.https://doi.org/10.1007/s00702014-1216-0.PMid:24752754, PMCid:PMC4134390

59. Yang C-J, Tan H-P, Du Y-J. The developmental disruptions of serotonin signaling mayinvolved in autism during early brain development. Neuroscience. 2014;267:1-10.https:// doi.org/10.1016/j.neuroscience.2014.02.021. PMid: 24583042

60. Lake CR, Ziegler MG, Murphy DL. Increased norepinephrine levels and decreased dopamine-âhydroxylase activity in primary autism. Archives of General Psychiatry. 1977; 34(5):553-6.https://doi.org/10.1001/ archpsyc.1977.01770170063005.PMid:558741

61. Lee M, Martin Ruiz C, Graham A, Court J, Jaros E, Perry R, et al. Nicotinic receptor abnormalities in the cerebellar cortex in autism. Brain. 2002;125(7):1483-95.https:// doi.org/10.1093/brain/awf160.PMid:12076999

62. Auranen M, Vanhala R, Varilo T, Ayers K, Kempas E, Ylisaukko-oja T, et al. A genomewide screen for autismspectrum disorders: evidence for a major susceptibility locus on chromosome 3q25-27. The American Journal of Human Genetics. 2002;71(4):777-90.https://doi.org/10.1086/ 342720.PMid:12192642, PMCid:PMC378535. 